\title{
TYPES OF INDIVIDUAL WOMEN EROTIC CODE
}

\author{
Sedykh K.V., *Zozul T.V. \\ Poltava V.G. Korolenko National Pedagogical University \\ Ostrogradsky Street, 2, Poltava, 36000, Ukraine \\ Poltava Business Institute, Private higher educational establishment \\ «Academician Yuriy Bugay International Scientific and Technical University» \\ Sinna Street, 7, Poltava, 36039, Ukraine \\ *E-mail: tamilazozul@gmail.com,http://orcid.org/0000-0003-0097-7113
}

Received 20 September 2018

The article is devoted to the current issue of sexuality. Significant expansion and development of psychologists' professional activity necessitate creating of generalized classification of individuals and married couples' behavioral erotic types. The destruction of selfreflection, self-perception and the difficulty of interpersonal understanding are due to the substitution of concepts. The study of sexual-psychological characteristics of behavioral patterns of women in erotic relationships is very important in this regard. The new material on the topic under study is generalized. Erotic imagination functions and erotic images impact on the process of forming a fixed erotic Image of a sexual partner in women are determined. The impact of early life experience (imprinting) influenced on the individual erotic code formation is determined. Several motivational schemes of sexual behavior are described. Authors submit the definition of «individual erotic code» for the first time. «Individual erotic code» is found out as the unified recording system of the individual model erotic behavior and her «ideal partner» reactions on this behavior. The types of women individual erotic code, based on the concept of archetypes (K.G. Jung, D. S. Bolen) study are defined. Types of individual erotic code were named after the ancient Greek goddesses: Artemis, Athena, Hestia, Hera, Demeter, Persephone, Aphrodite. The attention is focused on the deep analysis of individual women erotic code stages realization, such as, the genesis of erotic impulse, the tempting process, the sexual act behavior, the pregnancy, the caring of posterity. Materials of research can be used in the practical work of psychologists and psychotherapists which working both with married couples, as well as in individual work with the client.

KEY WORDS: individual erotic code, sexuality, sexual scenario, archetype, stage, the realization of individual erotic code.

\section{ТИПЫ ИНДИВИДУАЛЬНОГО ЭРОТИЧЕСКОГО КОДА У ЖЕНЩИН}

К.В. Седых, Т.В. Зозуль Полтавский национальный педагогический университет им. В.Г. Короленка ул. Остроградского, 2, г. Полтава, 36000, Украина Полтавский институт бизнеса МНТУ им. акад. Ю. Бугая ул. Сенная, 7, г. Полтава 36039, Украина

Расширение интересов в сфере современной психологии и развитие деятельности психологов вызывают необходимость создания обобщающей классификации эротических типов поведения как отдельных людей, так и супружеских пар. Подмена понятий приводит к деструкции саморефлексии, самовосприятия и вызывает существенные затруднения в межполовом понимании. В связи с этим актуальность исследования сексуально-психологических особенностей поведенческих паттернов женщин в эротических отношениях приобретает особое значение. Авторами обобщен новый материал по изучаемой теме. Обозначены функции эротического воображения и установлено влияние эротических образов на процесс формирования фиксированного эротического Образа сексуального партнера у женщин, который обусловливается усвоенным в процессе жизни ранним опытом (импринтингом). Описаны некоторые мотивационные схемы сексуального поведения. Впервые сформулировано понятие «индивидуальный эротический код», который представляет собой единую систему записи модели эротического поведения индивида и обратной реакции его «идеального партнера». На основании изучения концепции об архетипах, в статье выделены типы индивидуального эротического кода у женщин, которые получили название по именам древнегреческих богинь: Артемида, Афина, Гестия, Гера, Деметра, Персефона, Афродита. Особое внимание сконцентрировано на пристальном анализе этапов реализации индивидуального эротического кода у женщин: возникновении эротического импульса, процессе ухаживания, поведении во время эротического процесса, беременности и заботе о потомстве. Материалы исследования могут быть использованы в практической деятельности психологов и психотерапевтов при работе как с супружескими парами, так и в индивидуальной работе с клиентом.

КЛЮЧЕВЫЕ СЛОВА: индивидуальный эротический код, сексуальность, сексуальный сценарий, архетип, этап, реализация индивидуального эротического кода.

(C) Седых К. В., Зозуль Т. В., 2018 
ТИПИ ІНДИВІДУАЛЬНОГО ЕРОТИЧНОГО КОДУ У ЖІНОК

К.В. Седих, Т.В. Зозуль

Полтавський наџіональний педагогічний університет ім. В.Г. Короленка вул. Остроградського, 2, м. Полтава, 36000, Украӥна

Полтавський інститут бізнесу МНТУ ім. акад. Ю. Бугая вул. Сінна, 7, м. Полтава, 36039, Украӥна

Суттєве розширення і розвиток діяльності психологів зумовлюють необхідність створення узагальнюючої класифікації еротичних типів поведінки окремих людей та подружніх пар. Через підміну понять відбувається деструкція саморефлексії, самосприйняття та істотне утруднення міжстатевого порозуміння. У зв'язку з цим актуальність вивчення сексуальнопсихологічних особливостей поведінкових патернів жінок у еротичних стосунках набуває особливого значення. На основі теоретичного та емпіричного аналізу авторами узагальнено новий матеріал 3 досліджуваної теми. Означено функції еротичної уяви та вплив еротичних образів на процес формування фіксованого еротичного Образу сексуального партнера у жінок, який формується на основі засвоєного ними в процесі життя раннього досвіду (імпринтингу). Описано деякі мотиваційні схеми сексуальної поведінки. Вперше сформульовано поняття «індивідуальний еротичний код», який являє собою єдину систему запису моделі еротичної поведінки індивіда і зворотної реакції на неї «ідеального партнера». Тобто, специфічний тип поведінки індивіда, що спрямований на реалізацію сексуального завдання. У статті виокремлено типи індивідуального еротичного коду жінок, на основі вивчення концепції про архетипи, які отримали назву за іменами давньогрецьких богинь: Артеміда, Афіна, Гестія, Гера, Деметра, Персефона, Афродіта. Увагу сконцентровано на пильному аналізі етапів реалізації індивідуального еротичного коду у жінок: виникнення еротичного імпульсу, процесу залицяння, поведінки під час еротичного процесу, вагітності та турботи про потомство. Матеріали дослідження можуть бути використані в практичній діяльності психологів та психотерапевтів при роботі як із подружніми парами, так $\mathrm{i}$ в індивідуальній роботі з клієнтом.

КЛЮЧОВІ СЛОВА: індивідуальний еротичний код, сексуальність, сексуальний сценарій, архетип, етап, реалізація індивідуального еротичного коду.

\section{ПОСТАНОВКА ПРОБЛЕМИ}

Останнім часом в практиці сімейної психології і психотерапії назріла необхідність створення певної узагальнюючої класифікації еротичних типів поведінки як окремих людей, так і пар. Це зумовлено суттєвим розширенням і розвитком діяльності психологів, які працюють із подружніми парами. Сексуалізація культури коректує бачення сексуальності чоловіків та жінок, погляди на їх сексуальну активність у бік викривлення. Відбувається підміна понять, з'являються культурні новоутворення у вигляді специфічних соціальних міфів, що, в свою чергу призводить до деструктивної саморефлексії, негативно позначається на самосприйнятті, утруднює міжстатеве порозуміння та породжує проблеми в парах.

Тож, метою нашого дослідження стало виявлення типів індивідуального еротичного коду жінок.

Об'єктом дослідження виступають сексуально-психологічні особливості поведінки жінок в еротичних стосунках.

Предметом дослідження - особливості кожного типу еротичного коду у жінок.

Виклад основного матеріалу. Суть і сенс сексуальності людини намагаються розкрити різні концепції. Проте, еволюційні концепції не можуть роз'яснити, як в процесі еволюції виникає «сексуальна свідомість»; теологічні пояснюють сенс і мету життя (у тому числі й сексуальності) посмертною винагородою; психоаналітичні (Ф. Ференца, Е. Форма та ін.) - пояснюють сенс і мету сексуальності категоріями прагнення до повернення втраченої єдності з навколишнім середовищем, проте сенс і мета цього непідвладні свідомості людини. Подібний зміст, хоча і в прихованій формі, полягає і в інших концепціях, наприклад, в тантризмі, в індійській філософії, в біхевіористських поглядах. Вони повсюдно приймаються для пояснення причин сексуальних розладів та їх лікування, досліджують різні форми сексуальної поведінки, проте також не дають відповіді на питання про сенс і цінність сексуальної поведінки. 
Психосексуальна складова онтогенезу сексуальності включає процеси сексуальної поведінки, що змінюються, під впливом мислення, сприйняття, пам'яті, міркувань, уяви, емоцій, почуттів і інших психологічних аспектів людської сексуальної активності упродовж усього життя людини [1].

Сексологія та психологія сексуальності нині активно розвиваються як галузі наукових знань, i як наслідок, продовжують формувати свій понятійно-категоріальний апарат. Проте, багато термінів нерідко по-різному сприймаються представниками різних наукових шкіл, що створює передумови до плутанини у визначеннях, до невірних висновків при аналізі наукових робіт, неможливості ефективної комунікації в науковому співтоваристві при рішенні актуальних проблем. Категорії цього напряму піддаються регулярному перегляду, i однозначність думок з багатьох питань ще не сформувалася.

Оскільки сексуальність являє собою не лише реалізацію сексуальної функції, а й включає в себе когніції, емоції, фантазії, специфічну мотивацію індивіда, особливої актуальності набуває визначення індивідуальних еротичних параметрів, психологічних детермінант та поведінкових патернів жінок.

Ми дотримуємось думки, що сексуальність має відносну автономність, відносну незалежність від решти життя, тому іiі неможливо повністю оцінити тільки 3 етичної точки зору, пов'язати 3 трансцендентними чи релігійними цінностями.

Винятковою властивістю людини, притаманною ій, як свідчить історія мистецтва, 3 найдавніших часів $є$ здатність не тільки реагувати на еротичні знаки й образи, а й створювати їх, втілюючи в них свою фантазію.

Останнім часом досить широке розповсюдження отримало поняття сексуального сценарію. Так, I. Кон раніше визначав сексуальний сценарій як когнітивну структуру, що поєднує в собі багатоманітні символічні і невербальні елементи в організований та хронологічно послідовний поведінковий ряд, на основі якого люди можуть одночасно передбачати свою поведінку й оцінювати іiі в конкретний період часу. У більш пізніх роботах він дає інше визначення: «Сексуальний сценарій - це детермінована культурою і в значній мірі неусвідомлювана розумова схема, на основі якої люди організовують, осмислюють і оцінюють свою сексуальну поведінку» [4].

Проте, слід зазначити, що адаптуючись у рамках визначеної культури, люди засвоюють саме ті патерни сексуальної поведінки, які відповідають їх власним потребам [6]. Тому, окрім когнітивних елементів (понять, уявлень, оціночних суджень) в якості чинників, що визначають сексуальну поведінку людини, важливу роль відіграють також мотивація, поведінка та емоційні процеси. Сексуальний сценарій характеризує ту частину сексуальної культури, яка засвоєна індивідом у процесі життя, стала частиною його особистості і тому управляє його сексуальною поведінкою «зсередини», виступаючи як частина диспозиції.

Наша ідея полягає в тому, що системоуторюючим елементом сексуального сценарію людини $є$ іiі індивідуальний еротичний код.

Індивідуальний еротичний код особистості визначається нами, як специфічний тип поведінки індивіда для реалізації сексуального завдання, тобто, своєрідний меседж іншим особам протилежної статі. Це поняття, є близьким до понять «плану», «схеми» або «поведінкової програми». Воно дозволяє розкрити зміст сексуальної поведінки як соціально-психологічного феномену. Індивідуальний еротичний код - єдина система запису моделі еротичної поведінки індивіда у вигляді послідовності прояву власних реакцій та реакцій «ідеального партнера», запрограмована на реалізацію певного сексуального завдання. Ця система правил послідовності певних поведінкових реакцій надає кожному індивіду можливість кодування еротичної поведінки за допомогою послідовності обміну своєрідними еротичними сигналами з особами протилежної статі та співпадіння чи неспівпадіння їх із внутрішнім реагуванням Образу «ідеального партнера» [6]. 
Оскільки, індивідуальний еротичний код має трирівневу площину формування - символічну, поведінкову та семантичне поле - ми можемо говорити що, в період формування індивідуальноеротичного коду одним із ключових етапів є підлітковий вік. Гормональні зрушення цього етапу, стимулюють еротичну уяву підлітка і через механізм імпринтингу першого власного еротичного досвіду створюється - атрибут, який ми назвали «чинник А», щчо організовує світ сексуальних метафор $і$ в подальшому житті людини буде виступати тригером для виникнення потужного еротичного імпульсу (детальніше чинник А ми розглянемо в нашій наступній статті).

Внаслідок того, що сексуальна поведінка людини $\epsilon$ соціально-знаковою, вже саме розмежування «еротичних» $\mathrm{i}$ «нееротичних» стимулів правомірно лише в рамках переживання певної знакової і конкретної ситуації [2]. Переживання залежать від контексту в якому вони сприймаються, будь-які емоційні переживання припускають: 1) внутрішній емоційний стан збудження; 2) якісь пояснення, атрибуції цього стану [7]. Тож, різниця між «еротичними» та «нееротичними» переживаннями залежить від контексту.

У дослідженні з метою виявлення типів еротичного коду у жінок нами проведений грунтовний теоретичний аналіз та емпіричне дослідження. У емпіричному дослідженні взяли участь 130 жінок віком від 21 до 45 років.

В емпіричному дослідженні використані чотири групи методів дослідження: опитувальники («Методика для визначення сексуального темпераменту людини», «Методика вивчення сексуальності людини» (В.Й. Бочелюк, О.А. Черепєхіна)), аналіз наративів сексуальної взаємодії у досліджуваних, кількісний та якісний аналіз отриманих під час дослідження емпіричних даних.

Нами виділено декілька типів еротичного коду у жінок. Вони корелюють із певними архетипами, названими психологами-юнгіанцями за іменами давньогрецьких богинь: Артеміда архетип феміністки, Афіна - архетип вожака зграї (сестри для чоловіків), Гестія - архетип монахині (відлюдниці), Гера - архетип дружини, Деметра - архетип матері, Персефона - архетип доньки, Афродіта - архетип коханки [10].

В таблиці представлена типологія індивідуальних еротичних кодів у жінок (Артеміда, Афіна, Гестія, Гера, Деметра, Персефона, Афродіта).

Нами виокремлено поведінкові патерни еротичного коду різних видів: еротичний імпульс, залицяння, еротичний процес, вагітність, турбота про потомство.

Таблиця

Жіночі архетипи

\begin{tabular}{|c|c|c|c|c|c|c|}
\hline $\begin{array}{l}\text { Типи } \\
\text { еротичного } \\
\text { коду }\end{array}$ & $\begin{array}{l}\text { Внутрішні } \\
\text { установки }\end{array}$ & $\begin{array}{c}\text { Міжособистісні } \\
\text { контакти }\end{array}$ & \begin{tabular}{|c|} 
Сексуальна \\
активність/ \\
Потенція
\end{tabular} & $\begin{array}{c}\text { Мотивація/ } \\
\text { Ідеї про } \\
\text { сексуальність }\end{array}$ & $\begin{array}{c}\text { Стратегіï } \\
\text { поведінки }\end{array}$ & $\begin{array}{c}\text { Еротичний } \\
\text { процес }\end{array}$ \\
\hline Артеміда & Незалежність & $\begin{array}{l}\text { Відособлення, } \\
\text { «полювання» }\end{array}$ & Середня & $\begin{array}{l}\text { Утримання, } \\
\text { фізична насолода }\end{array}$ & $\begin{array}{l}\text { Завойовування, } \\
\text { рішучість }\end{array}$ & $\begin{array}{l}\text { Домінування, } \\
\text { перевага }\end{array}$ \\
\hline Aфіна & $\begin{array}{l}\text { Повага, } \\
\text { прихильність }\end{array}$ & $\begin{array}{l}\text { Ототожнення себе } \\
3 \text { чоловіками, } \\
\text { рівноправність } \\
\text { уважність }\end{array}$ & Низька & \begin{tabular}{|l|} 
Розрахунок, \\
дітонародження, \\
фізіологічна \\
потреба
\end{tabular} & $\begin{array}{l}\text { Лестощі, } \\
\text { дружня участь, } \\
\text { протекція }\end{array}$ & $\begin{array}{l}\text { Навмисний акт, } \\
\text { концентрація на } \\
\text { техніці статевого } \\
\text { акту }\end{array}$ \\
\hline Гестія & $\begin{array}{l}\text { Невинність, } \\
\text { аскетизм }\end{array}$ & $\begin{array}{l}\text { Уникнення, } \\
\text { відособлення, } \\
\text { відчуженість }\end{array}$ & Низька & $\begin{array}{l}\text { Утримання, } \\
\text { дітонародження, } \\
\text { задоволення } \\
\text { фізіологічних } \\
\text { потреб чоловіка }\end{array}$ & $\begin{array}{l}\text { Покірливість, } \\
\text { скромність, } \\
\text { соромливість }\end{array}$ & Поступливість \\
\hline
\end{tabular}




\begin{tabular}{|c|c|c|c|c|c|c|}
\hline \begin{tabular}{|l} 
Типи \\
еротичного \\
коду
\end{tabular} & $\begin{array}{l}\text { Внутрішні } \\
\text { установки }\end{array}$ & $\begin{array}{c}\text { Міжособистісні } \\
\text { контакти }\end{array}$ & $\begin{array}{c}\text { Сексуальна } \\
\text { активність/ } \\
\text { Потенція }\end{array}$ & $\begin{array}{c}\text { Мотивація/ } \\
\text { Ідеї про } \\
\text { сексуальність }\end{array}$ & $\begin{array}{c}\text { Стратегії } \\
\text { поведінки }\end{array}$ & $\begin{array}{l}\text { Еротичний } \\
\text { процес }\end{array}$ \\
\hline Гера & Заміжжя & $\begin{array}{l}\text { Проникливість, } \\
\text { активність }\end{array}$ & Низька & $\begin{array}{l}\text { Заміжжя, } \\
\text { задоволення } \\
\text { фізіологічних } \\
\text { потреб чоловіка }\end{array}$ & $\begin{array}{l}\text { Приєднання, } \\
\text { ведення }\end{array}$ & $\begin{array}{l}\text { Задоволення } \\
\text { потреб чоловіка, } \\
\text { активність/ } \\
\text { пасивність }\end{array}$ \\
\hline Деметра & Материнство & Опіка, турбота & Низька & Дітонародження & $\begin{array}{c}\text { Завойовування, } \\
\text { рішучість }\end{array}$ & $\begin{array}{l}\text { Задоволення } \\
\text { потреб чоловіка, } \\
\text { активність/пасив } \\
\text { ність }\end{array}$ \\
\hline Персефона & Захист & $\begin{array}{l}\text { «Підлаштову- } \\
\text { вання» під } \\
\text { партнера }\end{array}$ & Низька & Опіка & $\begin{array}{l}\text { Відгук на } \\
\text { активність } \\
\text { чоловіка }\end{array}$ & $\begin{array}{l}\text { Задоволення } \\
\text { потреб чоловіка }\end{array}$ \\
\hline Aфродіма & \begin{tabular}{|l|} 
Еротика, \\
незалежність
\end{tabular} & $\begin{array}{l}\text { Романтизація } \\
\text { стосунків, } \\
\text { активність }\end{array}$ & Висока & Пізнання & $\begin{array}{l}\text { Еротичні } \\
\text { прийоми, } \\
\text { зваблення }\end{array}$ & $\begin{array}{l}\text { Романтичний } \\
\text { секс, чуттєва } \\
\text { насолода }\end{array}$ \\
\hline
\end{tabular}

Реалізація еротичного коду за типом Артеміда:

$\checkmark \quad$ Еротичний імпульс. Ї̈̈ збуджує конкуренція, ідеалізація об'єкту.

$\checkmark \quad$ Залицяння. Сама обирає партнера, проявляє ініціативу, може бути настирливою i агресивною, iї не цікавить чи сподобалась вона партнеру.

$\checkmark \quad$ Еротичний процес. Сексуально збудлива, розкута, має схильність до експериментів. Секс жінка 3 даним типом еротичного коду сприймає як дослідження. Характеризується високим лібідо. Здатна отримувати сексуальне задоволення. У сексі схильна до демонстрації типової маскулінної поведінки (домінування) - влади, настирливості, активності.

$\checkmark \quad$ Bazimнicmb. Діти не $є$ пріоритетом для Артеміди. Часто жінка не хоче реалізуватися в материнстві. Домінує реалізація себе в роботі над сімейним життям. Важливим є збереження фігури.

\section{$\checkmark \quad$ Турбота про потомство. Забезпечення фізіологічних потреб дитини.}

Реалізація еротичного коду за типом Афіна:

$\checkmark \quad$ Еротичний імпульс. Жінку збуджує досягнення високого соціального статусу та влади, які вона може отримати за допомогою чоловіка-покровителя.

$\checkmark \quad$ Залиияння. Характеризується маскулінним типом поведінки. Легко встановлює міжособистісні стосунки з чоловіками, в яких позиціонує себе як подруга, соратниця, сестра. Схильна до лестощів, маніпуляцій.

Еротичний процес. Секс для Афіни є чітко обміркованим навмисним актом, що спрямований, здебільшого, на досягнення позасексуальних цілей. Тому у сексі вона концентрується на техніці процесу. Ставиться до сексу як до задоволення фізіологічної потреби.

$\checkmark \quad$ Bazimність. Для Афіни реалізація в материнстві виступає способом підвищення соціального статусу в групі.

\section{$\checkmark \quad$ Турбота про потомство. Забезпечення фізіологічних потреб дитини.}

Реалізація еротичного коду за типом Гестія:

$\checkmark \quad$ Еротичний імпульс. Схильна до певного сексуального аскетизму, тобто, не важливо отримує задоволення жінка в процесі статевого акту, або ж ні - аспект життя, пов'язаний 3 
сексуальністю, та будь-якими проявами еротики є для неї неважливим.

$\checkmark \quad$ Залиияння. Жінка не схильна до флірту та короткострокових інтрижок. Здебільшого займає пасивну позицію. Характеризується очікуванням активності з боку чоловіків.

$\checkmark \quad$ Еротичний процес. Жінка 3 типом еротичного коду Гестія здатна до «сексуальної реактивності», тобто в процесі статевого акту вона не потребує довгої прелюдії та отримує повне задоволення. Якщо жінка $є$ аноргазмічною, сексуальні контакти з чоловіком приносять їй фізичне задоволення (пестощі, тактильний контакт) та психологічне (через задоволення чоловіка). Вона характеризується низьким сексуальним темпераментом, при високій сексуальній поступливості.

$\checkmark \quad$ Baziтність. Діти ії не цікавлять.

$\checkmark \quad$ Турбота про потомство. Якщо діти народжуються, жінка мало приділяе їм глибокої уваги.

Реалізація еротичного коду за типом Гера:

$\checkmark$ Еротичний імпульс. Якщо жінка незаміжня, знаходиться в пошуку шлюбного партнера, iї головна мета - заміжжя. Еротичний код починає реалізуватися часто після заручин або заміжжя, оскільки для жінки 3 цим еротичним кодом заміжжя та сексуальність $є$ нероздільними поняттями.

Залиияння. Стосунки 3 потенційним партнером не мають емоційної глибини та духовної близькості. Характеризується специфічними прийомами для зваблення, в яких намагається презентувати себе як «ідеальну дружину» (надійну людину, турботливу, здатну турбуватися, забезпечувати побут).

$\checkmark \quad$ Еротичний процес. Еротичні прийоми використовуються жінками здебільшого для приваблення чоловіка та реалізації свого найсильнішого внутрішнього потягу - заміжжя.

$\checkmark \quad$ Bazimність. Зазвичай сприймається позитивно, оскільки дає змогу жінці відчути себе повноцінною дружиною, та є гарантією збереження шлюбу.

$\checkmark \quad$ Tурбота про потомство. Виступає як хороша мати на рівні забезпечення побутових потреб. Не завжди емоційно тепла, адже в їі емоційних прив'язаностях домінує чоловік, а не діти.

Реалізація еротичного коду за типом Деметра:

$\checkmark \quad$ Еротичний імпульс. Здебільшого виникає як відгук на активність чоловіка, як при флірті та більш близькому знайомстві, так і в еротичному процесі.

$\checkmark \quad$ Залиияння. Жінки вибирають партнера самостійно. Провокують до близькості. Часто чоловік жінки 3 типом еротичного коду Деметра характеризується емоційною незрілістю, невпевненістю в собі, іiї партнер психологічно слабший за неї та має труднощі в соціальній реалізації. Такі жінки схильні утворювати пару з чоловіком із великою різницею у віці.

Еротичний процес. Характеризуються низьким сексуальним темпераментом, та, відповідно, низькою сексуальною мотивацією. Секс для жінки не є ані насолодою, ані фізіологічною потребою. Першочергово, виступає виключно інструментом для продовження роду та задоволення фізіологічних потреб чоловіка.

$\checkmark \quad$ Bazimнicmb. Сприймається дуже позитивно, адже головна мета життя жінки - мати дітей/бути матір'ю.

Турбота про потомство. Еротичний код реалізується через материнство. При дослідженні встановлено, що насолода від тактильних контактів з новонародженим, єднання 3 ним, виступає більш вагомим та інтимним засобом насолоди, аніж секс із чоловіком.

Реалізація еротичного коду за типом Персефона:

$\checkmark \quad$ Еротичний імпульс. Виникає несвідомо до чоловіків певного типу («образ батька»).

$\checkmark \quad$ Залицяння. Жінки схильні проявляти фемінний тип поведінки, схильні фліртувати та провокувати зворотній інтерес, що викликає у чоловіків бажання піклуватися та захищати. 
$\checkmark$ Еротичний прочес. Характеризуються сексуальною поступливістю, пасивністю, слабкістю. Реалізація еротичного коду відбувається, здебільшого, несвідомо, оскільки недостатні саморегуляція та саморозуміння не сприяють цьому.

$\checkmark \quad$ Bazimність. Часто за бажанням чоловіка.

$\checkmark \quad$ Турбота про потомство. Конкуренція з дітьми за увагу та опіку чоловіка.

Реалізація еротичного коду за типом Афродіма:

$\checkmark \quad$ Еротичний імпульс. Жінки мають високий сексуальний потенціал, еротичні імпульси виникають часто. Вони легко закохуються, слідують своїм еротичним потягам.

$\checkmark \quad$ Залиияння. Активні. Проявляють інтерес до чоловіків. Мають велику кількість романтичних стосунків із різними чоловіками. Афродіта знаходить спільний з чоловіками інтерес в них самих, таким чином провокуючи зворотній інтерес.

$\checkmark$ Еротичний процес. У еротичних стосунках здатні зосереджуватися на власних відчуттях та ототожнюють секс з насолодою.

$\checkmark \quad$ Bazimнiсть. Насолоджується своїм станом, якщо це відповідає іiі бажанням або перериває вагітність, якщо це заважає її власній реалізації.

$\checkmark \quad$ Турбота про потомство. Любить дітей, турбується про них, але частіше передовіряє обов'язки іншим людям.

Висновки. Отже, у статті виокремлено та охарактеризовано типи індивідуальноеротичного коду жінок. Авторами також виділено та охарактеризовано типи індивідуального еротичного коду у чоловіків: Зевс, Аполлон, Гадес, Гермес, Арес, Гефест, Діоніс. Детальний опис типів буде представлено у подальшому науковому дослідженні.

Перспективи подальших розвідок полягають у дослідженні компліментарності жіночого та чоловічого індивідуального еротичного коду в парі, існування спільного коду пари та можливості змін коду у кожного з партнерів у процесі довготривалих постійних парних інтимних стосунків.

\section{СПИСОК ЛІТЕРАТУРИ}

1. Agarkov S.T., Kaschenko E.A. Сексуальность в цивилизации: от пещер до небоскребов (социогенез сексуальности). Учебное пособие к курсу «Психологическое консультирование в сексологии». [Sexuality in civilization: from caves to skyscrapers (sociogenesis of sexuality). A manual for the course "Psychological counseling in sexology"]. - Voronezh: Nauchnaya kniga, 2010. - 491 p. (in Russian)

2. Bochelyuk V.Y., Cherepehina O.А. Психологія сексуальності: навчальний посібник для студентів спеціальності 8.03010201 - психологія [Рsychology of sexuality: primary counseling for students of special conditions 8.03010201 - psychology]. - Kyiv: Skif, 2012. - 312 p. (in Ukrainian)

3. Imelinskiy К. Сексология и сексопатология [Sexology and Sexopathology]. - Moscow: Medicina, 1986. 424 p. (in Russian)

4. Kon I.S. Сексология: Учебное пособие для студентов высших учебных заведений [Sexology: A textbook for students of higher educational institutions]. - Moscow: Akademiya, 2004. - 384 p. (in Russian)

5. Kocharyan A.S., Zhidko M.E., Tereschenko N.N., Frolova E.V. Полоролевая психология: коллективная монография. [Sex-Role Psychology: A Collective Monograph]. - Harkiv: HNU imeni V.N. Karazina, 2015. 236 p. (in Russian)

6. Sedih K., Zozul' Т. Індивідуальний еротичний код у роботі з подружньою парою [Individualnyy oticheskiy code for the robot with a spouse] // Psihologichne konsul'tuvannya i psihoterapiya [Psychological consultation and psychotherapy]. - 2017. - № 7 (1). - C. 38-45. (in Ukrainian)

7. Shehter S., Singer Dzh. Когнитивные, социальные и физиологические детерминанты эмоционального состояния // Психология мотивации и эмоций [Cognitive, social and physiological determinants of the emotional state // Psychology of motivation and emotions]. / Red. Yu.B. Gippenreyter, M.V. Falikman. - Moscow: CheRo, 2002. - P. 462-480. (in Russian)

8. Yung K.G. Архетипы и символы [Archetypes and Symbols]. - Moscow: Renessans, 1991. - 292 p. (in Russian)

9. Yung K.G. Об архетипах колективного бессознательного [On the archetypes of the collective unconscious] // 
Vopr. Filosofii. - 1988. - № 1. - P. 131-138. (in Russian)

10. Bolen J. Goddesses in Everywoman: Powerful Archetypes in Women's Lives. Thirtieth Anniversary Edition. New York: Harper Collins Publishers Inc, 2014. - 368 p. 